\title{
DIGITALCOMMONS
}

@WAYNESTATE-

Wayne State University

$1-1-2010$

\section{Straightening Up: Black Women Law Professors, Interracial Relationships and Academic Fit(ting) In}

Adele M. Morrison

Wayne State University, ammorrison@wayne.edu

\section{Recommended Citation}

Adele M. Morrison, Straightening Up: Black Women Law Professors, Interracial Relationships and Academic Fit(ting) In, 33 Harv. J.L. \& Gender 85 (2010).

Available at: https://digitalcommons.wayne.edu/lawfrp/212 


\title{
STRAIGHTENING UP: BLACK WOMEN LAW PROFESSORS, INTERRACIAL RELATIONSHIPS, AND ACADEMIC FIT(TING) IN
}

\author{
AdEle M. Morrison*
}

\section{INTRODUCTION}

In Making Up Is Hard to Do: Race/Gender/Sexual Orientation in the Law School Classroom, ${ }^{1}$ Professors Robert Chang and Adrienne Davis write of the tools that people of color, women, and lesbian, gay, bisexual, and transgender ("LGBT") persons use in order to fit into the role of law professor. They further explore how those same groups are perceived, received, and evaluated by students and colleagues. Through this epistolary exchange, the authors explain the frequently gendered and racialized armor law professors of color don and the tactics we employ in order to pursue acceptance and advancement in the legal academy. Chang and Davis discuss the "gendered tools" of clothing and make-up ${ }^{2}$ we use to construct the visible physical image that is projected in the classroom, and the impact that image-and the effort to create it-has on both the students and professor. They also confront choices to reveal, or conceal, aspects of identity that may be less readily apparent, such as sexual orientation and relationship status.

In this essay I join in the exploration of the "(im)possibility of Black women and Asian men performing certain identities, specifically, as law professors." 3 Narrowing my attention to the particular subset of the groups addressed by Chang and Davis to which I belong-Black ${ }^{4}$ women law

* Associate Professor of Law, Wayne State University Law School; LLM Wisconsin Law School; JD Stanford Law School, BA San Francisco State University. The ideas behind this essay have been germinating for several years, only able to finally find form because Professors Davis and Chang have published their exchange. Much thanks goes to them and also to the group of scholars with whom I have engaged on these very issues over the years. They include, but are not limited to: Camille Nelson, Catherine Smith, Angela Onwuachi-Willig, Frank Rudy Cooper, Rashmi Goel, Reggie Oh, Christian Halliburton, and Jennifer Chacón, and in a separate, but equally vital contexts Adrienne Davis and Bob Chang themselves. My biggest thanks go to CJB who has many fine attributes, not the least of which are great editing skills.

Robert S. Chang \& Adrienne D. Davis, Making Up Is Hard to Do: Race/Gender/ Sexual Orientation in the Law School Classroom, 33 HARv. J. L. \& GeNDER 1 (2010).

${ }^{2}$ Chang \& Davis, supra note 1, at 2-11 ("Letter 1: Fancy Clothes"); Chang \& Davis, supra note 1, at 3 (responding to wearing "fancy clothes").

${ }^{3} I d$. at 3 .

${ }^{4}$ See Kimberlé Crenshaw, Mapping the Margins: Intersectionality, Identity Politics and Violence Against Women of Color, 43 STAN. L. Rev. 1241, 1244 n.6 (1991) (explaining why Black is capitalized while white is not, "I capitalize 'Black' because 'Blacks, like Asians, Latinos, and other "minorities," constitute a specific cultural group and, as such, require denotation as a proper noun.' By the same token, I do not capitalize 'white,' which is not a proper noun, since whites do not constitute a specific cultural group." (citation omitted)). 
professors-and using the potentially hidden identity marker of relationship status as my exemplar, I employ hairstyling, specifically the process of straightening Black hair, as a metaphor for the manner in which law students and faculties construct an identity for a law professor. Further, I examine how students and faculties use that identity in questioning whether a professor fits into a given academic environment. I will use my own experience as a member of an even narrower subset of law professors-Black women in interracial relationships - to theorize that the straightening process can be applied not only to Black hair but also to Black identity. This straightening is the process that students and faculties go through to incorporate the presence of Black women in the law school environment into their own visions and experiences of it. Straightening does to our racial identity what the chemicals of relaxers or the heat of pressing combs does to our hair-it makes us (seem) whiter. In my interracial relationship example, through intimate involvement with whiteness, my identity as a Black woman is straightened up. 5 This "straightening" means that my standing is raised or I am given more legitimacy in the eyes of the majority of white professors and law students.

This essay, grounded in Making Up Is Hard To Do, enters Chang and Davis's law school environment and introduces into it the concept of 'straightening.' Part II establishes the idea of straightening, addressing the process as it applies to hair and racial identity. Part III explores straightening in the context of relationships. Part IV considers straightening in the context of academic fit and the law school environment. I conclude the essay by noting that hair styling can indeed serve as a useful metaphor for at least some of us who perform the role of law professor.

\section{Straightening: Of Hair and Race}

Hair has been and still is a culturally charged topic, imbued with disproportionate significance. ${ }^{6}$ The debates over hair and hairstyles are espe-

\footnotetext{
${ }^{5}$ This theory is particularized to Black women not only because I am approaching it from my own subject position, but also because of the heightened intersectional discrimination Black women face based on the way that race and gender work together in both the contexts of hair and identity. This is not to say that white women, Black men, or other people of color do not struggle with and against dominant cultural norms, but it is to directly acknowledge the specific impact that whiteness has on Black women.

${ }^{6}$ See generally Ingrid Banks, Hair Matters: Beauty, Power and Black Women's Consciousness (2000); Ayana D. Byrd \& Lori L. Tharps, Hair Story: Untangling THE Roots of Black Hair in AMerica (2001) (giving a history of Black hair in America); Paulette M. Caldwell, A Hair Piece: Perspectives on the Intersection of Race and Gender, 1991 Duke L.J. 365 (1991); Ashleigh Shelby Rosette \& Tracy L. Dumas, The Hair Dilemma: Conform to Racial Expectations or Emphasize Racial Identity, 14 Duke J. Gender L. \& Pol'y 407 (2007); Pamela J. Smith, Teaching the Retrenchment Generation: When Sapphire Meets Socrates at the Intersection of Race, Gender, and Authority, 6 WM. \& MARY J. WoMEN \& L. 53 (1999) (describing socio-political-cultural impact of hair and hairstyles on Black women).
} 
cially salient for Black women because, as Chang and Davis discuss, hair is "not a point just about race; rather, it is a classic intersectional point." It is at this intersection that Black women experience the "interactive effects of racial and gender discrimination." 8 As Paulette M. Caldwell writes, "Black women are the immediate, although not exclusive, physical and material representation of the intersection of race and gender." "Black women bear the brunt of racist intimidation resulting from western standards of physical beauty," 10 and thus "[h]air becomes a proxy for legitimacy and determines the extent to which individual [b]lacks can 'crossover' . . . into the mainstream of American life."ll Oprah Winfrey and Michelle Obama, among others, have had their hair and hairstyles scrutinized and debated in public fora. ${ }^{12}$ Even eleven-year-old Malia Obama's hairstyle has been criticized. ${ }^{13}$ Black women law professors' hairstyles have not escaped inquiry, at least within the law school environment. ${ }^{14}$ Pamela Smith discusses physical appearance, including hair, in the context of what she refers to as, "[T]he $[P]$ henomenon of [A]ppearance [H]ostility."15 She writes, "I found that students critiqued my clothing and hair and used both to solidify their image of me as threatening, intimidating, and angry." 16 She specifically discusses hair and the impact of her hairstyling in a section entitled "Hair as Threatening and Intimidating," 17 and she mentions the difference between an

In this essay I engage in a discussion of Black women and hair for the purposes of constructing my straightening analogy. The actual debate over straightened versus natural hair is much more complex, and has been going on in the United States for at least a century. See generally BYRD AND THARPS, supra note 6 . To give it the full and rich treatment that it deserves is beyond the scope of this essay. Thus, the cites I select are those which are most illustrative of my particular point, and I acknowledge the short shrift I am giving to any and every side in what continues to be a contentious debate.

${ }^{7}$ Chang \& Davis, supra note 1 , at 10 (citations omitted).

${ }^{8}$ Caldwell, supra note 6 , at 366 (describing the basis for the claim made by the plaintiff in Rogers v. American Airlines, 527 F. Supp. 229 (S.D.N.Y. 1981), where the court upheld the employer's right to ban the wearing of braided hairstyles).

Id. at 372 .

${ }^{10}$ Id. at 383 .

1 Id.

12 See Anya Strzemien, Oprah Defends Her Hair: "This Is Not A Weave", HuFFINGTON Post, April 25, 2009, http://www.huffingtonpost.com/2009/04/24/oprah-defends-her-hair-th_n_191287.html; Erin Aubry Kaplan, The Michelle Obama Hair Challenge, SALON, Feb. 3, 2009, http://www.salon.com/mwt/feature/2009/02/03/ michelle_hair/.

${ }^{13}$ See Catherine Saint Louis, Black Hair, Still Tangled in Politics, N.Y. Times, Aug. 27, 2009, at E1, available at http://www.nytimes.com/2009/08/27/fashion/27SKIN html?_r =1\&sq=Michelle\%20Obama\%20Hair\&st =cse\&adxnnl=1\&scp =1\&adxnnlx $=$ 1253394221-3AIxa7yarYJxJoUWi0sifQ.

${ }^{14}$ See, e.g., Anita Allen, On Being a Role Model, 6 Berkeley Women's L.J. 22, 40 (1990-1991) ; Caldwell, supra note 6; Smith, supra note 6, at 150-57.

${ }^{15}$ Smith, supra note 6, at 146.

${ }^{16} I d$. at 146

${ }^{17}$ Id. at 150 . 
"Afrocentric" hairstyle"-one I describe as natural ${ }^{18}$ - and a "permed straight" style, which she notes, "could be characterized as being assimilationist." 19 Straight hair is the standard by which Black female hair is determined to be "good" or "bad." 20 The straighter one's unprocessed hair is, the more it is culturally constructed as "good" hair. ${ }^{21}$ Though there is only anecdotal evidence, it is accepted as true that the majority of Black women in the United States wear their hair straight. ${ }^{22}$ In this piece, I use the process of straightening Black hair as a metaphor for the process of straightening one's identity.

For those unfamiliar with the styling of Black hair, there are two main ways to straighten it: 1) relaxing or perming, and 2) pressing or hot combing. Relaxing/perming is "[To] chemically alter[ ] [hair] by applying sodium hydroxide (lye) or calcium hydroxide (no lye) to loosen the curl or coil of tightly coiled or curled [B]lack hair. As a result the hair becomes straight after the chemicals are applied." 23 Pressing or hot combing is to "straighten[ ] by heat, by using the pressing comb." ${ }^{24}$ This process is con-

${ }^{18}$ This is not meant to be dismissive of Black-identified individuals with naturally straight hair, but only to define hair that is not chemically or heat altered. See Banks, supra note 6, at 171 (listing the varieties of textures of "natural" hair).

${ }^{19}$ Smith, supra note 6, at 150 .

${ }^{20}$ See Banks supra note 6, at 172; BYrd \& Tharps, supra note 6, at 159; Greg Braxton, Chris Rock Finds the Humor in 'Good Hair', L.A. Times, Oct. 4, 2009, available at http://articles.latimes.com/2009/oct/04/entertainment/ca-rock4. Braxton discusses Good Hair, a documentary film produced by comedian Chris Rock, whose interest in the subject of Black hair was reignited when "[o]ne day, one of [his] daughters came to [him] crying and saying, 'Daddy, why don't I have good hair?" " Braxton also mentions the 1988 Spike Lee film School Daze, which featured a musical number in "a beauty salon where two warring female college cliques - the 'Wannabes' and the 'Jigaboos' battled over 'Good and Bad Hair.'" Id.

${ }^{21}$ BANKs, supra note 6 , at 172 (defining "good hair" as that which is characteristically straighter, while "bad hair" is that which is characteristically kinkier); see also David K. Shipler, A Country of Strangers: Blacks and Whites in America 255 (1997) ("Whatever resembles the European model is valued by whites, even by many [B]lacks." "Good hair" means straight or wavy, not kinky and African-looking.).

${ }_{22}$ See, e.g., Rosette and Dumas, supra note 6, at 411 ("Chemically-relaxed hair is currently the most popular style choice for Black women."); bell hooks, Straightening Our Hair, Z MAGAZINE, Sept. 1988, available at http://www.zmag.org/zmag/viewArticle/ 13843 ("The vast majority of [B]lack women seated [at her lecture] had straightened hair.").

${ }^{23}$ BANKs, supra note 6 , at 172 . There are websites for non-chemical relaxers that won't burn your scalp, but my favorite response to the question "Does anyone know of a NON-chemical relaxer for ethnic women hair?" posted on "Yahoo! Answers" was "[T]here aren't any non-chemical relaxers." Postings of Ann \& sweetness22, http:// answers.yahoo.com/question/index?qid =20081206134738AALU0Yy (Dec. 16, 2008, 13:47:38 PST) (on file with Harvard Law School Library).

${ }^{24}$ BANKs, supra note 6, at 172 . 
trasted to wearing one's hair in a natural style such as an Afro, ${ }^{25}$ or dreadlocks, ${ }^{26}$ my hairstyle of choice for nearly two decades.

Ingrid Banks, author of Hair Matters: Beauty, Power and Black Women's Consciousness, writes: "For some [B]lacks, relaxed or permed hair is perceived as rejecting tightly coiled [B]lack hair and therefore [B]lack physical characteristics." 27 Ayana D. Byrd and Lori L. Tharps track the history of Black hairstyles in their book Hair Story: Untangling the Roots of Black Hair in America, noting that, "By the early 1900s, straight hair had become the preferred look to signal middle-class status." 28 Straightening hair was an effort to be "'a cookie cutter ... of White America." 29 Byrd and Tharps continue into the twentieth century, discussing the first Black Barbie which was introduced in 1980 and had "long loosely curled hair." 30 They further note that the "beauty standards in this country are set according to a [W]hite aesthetic_-from Miss America to the Barbie doll_-Black women are left with precious few places to turn to find an image of beauty that showcases unstraightened tresses and natural hairstyles." 31 These are examples of the notion that straightened hair brings one closer to an Americanwhite-ideal. ${ }^{32}$ Straightening is whitening. Whitening is bettering. Therefore straightening is bettering. It is bettering in that it makes Black women more acceptable in environments dominated by whites-in this case, law schools.

My assertion is that Black identity can go through the same process as Black hair. In the way that chemicals or heat are applied to kinky hair to tame it and straighten it out, identity markers more culturally assigned to whites and, in the case of interracial relationships, whiteness itself, are ap-

${ }^{25}$ Id. (noting that "[s]ome natural styles such as the Afro are referred to as nappy or kinky hair.").

${ }^{26}$ Dre[a]dlocks-What happens when nappy hair is left to its own devices. Sometimes achieved by twisting the hair first, then leaving it alone until the individual strands of hair begin to lock around each other to form a ropelike appearance. Does not require wax or glue or other foreign objects. Does not requ[i]re abstaining from regular hair hygiene, i.e. washing and conditioning. Once hair is locked, it cannot be unlocked.

BYrd \& Tharps, supra note 6, at 139.

${ }^{27}$ BANKs, supra note 6 , at 172.

${ }^{28}$ BYRD \& THARPS, supra note 6 , at 30 .

${ }^{29} \mathrm{Id}$. at 30 (quoting Harriett Cole)

${ }^{30} \mathrm{Id}$. at 155 .

${ }^{31} I d$. at 154

${ }^{32}$ In this hair debate, I hope not to sound like I am judging the majority of women who choose to straighten their hair, just as I hope they would not judge me for choosing dreadlocks. Besides the freedom to have whatever hairstyle one wishes, there are valid arguments for having straightened hair, i.e., it is easier to deal with. My working mother started sending me to have my hair chemically relaxed while in elementary school. I then had and now have a lot of thick and kinky hair and there simply was no time to deal with the intricacies of braiding, for example. When my hair was straightened, she could pull it back into a ponytail, which looked neat and tidy. Straightened hair is also hair that a girl can learn to deal with by herself at a much younger age. 
plied to Blacks to tame us and straighten us up. Straightening is essentially the assigning of whiteness to any aspects of our identity that can be construed as positive. Straightening emerges from the notion that whiteness has to have something to do with why Blacks are able to even exist in a white dominated environment. Though the default belief may be that our presence in white dominated institutions, including the legal academy, is only because of affirmative action-Black women being a "two-fer" after all ${ }^{33}$-it is nevertheless necessary for whites to find a way to deal with our presence. The reality that we are in law schools means we do the jobs of law professors. We teach classes, assign grades, vote on appointments, and hold other important responsibilities. Student and faculty members must cope with that reality, and so they construct us as white(ish) whenever they can. They straighten us up, meaning we are constructed as being closer to or associated with whiteness, even if that whiteness is only visible to those doing the straightening. Straightening, however, does not necessarily lead to acceptance or even tolerance. It primarily serves as a way for whites to handle the presence of people of color, specifically Black women, in the legal academy.

Straightening is different than "passing," 34 "covering," 35 or "shifting." ${ }^{\prime 36}$ Passing, covering, and shifting are decisions made by the individual about how to reveal or perform a particular identity, whereas others impose straightening upon an individual. When passing, covering, or shifting, the non-majority person is the subject, and she chooses what to do with particular subordinate or dominant identity markers. When straightening occurs, the non-majority person is the object onto which dominant identity markers are projected. Straightening is the process that leads to the change in hair and racial identity, as perceived by or projected from the outside. The process of straightening, whether of hair or identity, allows different people to attach different meanings to what has been straightened. As noted above,

${ }^{33}$ See Chang \& Davis, supra note 1, at 30-31 ("Two-fer" is a colloquialism that reflects the idea that women of color are hired because we get counted twice "for the purpose of [a] law school or university [faculty diversity report]."). (2006).

${ }^{34}$ See Angela Onwuachi-Willig, Undercover Other, 94 CAL. L. Rev. 873, 874 n.4

"[P]assing" has many manifestations, only one of which has to do with a member of a socially disadvantaged group pretending to be a member of a social group with greater social capital . . . [There is also] "in-group passing," which embraces the notion that, . . . racial group membership is conferred not just based on skin color but also on social behavior .... . [This also] involves hiding, even if only temporarily, or remaining silent about those behaviors or circumstances that would undermine one's in-group status. Id.

${ }^{35}$ Kenji Yoshino, Covering: The Hidden Assault on our Civil Rights ix (2006) ("To cover is to tone down a disfavored identity to fit into the mainstream."); id. at 18 ("[Erving] Goffman [who coined the term covering] distinguishes passing from covering by noting that passing pertains to the visibility of a particular trait, while covering pertains to its obtrusiveness.")

${ }^{36}$ See Rosette \& Dumas, supra note 6, at 415 (describing shifting as "altering one's behavior to avoid offending others"). 
straight hair can be perceived as being white hair, and Blacks with straighter hair can be perceived as being whiter. Whites outnumber Blacks in most law school communities, ${ }^{37}$ and since people are most familiar with and comfortable with their own race, most law students will be most familiar with whiteness and those characteristics that are attached to it. Straight(ened), whether in terms of hair or racial identity, is what strikes most members of law school communities as similar to themselves. The majority identify as straight in a myriad of ways, and they seek to fit in with others who identify that way as well, whether the others are students or professors.

Law schools are conventional institutions and therefore prefer their environments to be straight. Not only straight as in heterosexual, ${ }^{38}$ but also straight in all the ways it has been and can be used. ${ }^{39}$ Three of many dictionary definitions are "free from curves, bends, angles or irregularities," 40 "properly ordered or arranged," 41 and "exhibiting no deviation from what is established or accepted as usual, normal, or proper." 42 Hippies and other sub- or counter-cultural groups have set themselves, or were set, in opposition to straights. ${ }^{43}$ Straight is also used in opposition to criminality, as exemplified by the 1978 documentary Scared Straight ${ }^{44}$ In the context of Black hair, straight manifests itself in the competition between straight(ened)/relaxed and natural/nappy/kinky. ${ }^{45}$ In each pairing, straight is constructed as being better than that against which it is juxtaposed. Straight fits society's standards, ${ }^{46}$ and viewing the legal academy as a microcosm of that society, it follows that the straighter one is, the better one seems to fit into the academy.

${ }^{37}$ Law School Admission Council, Data: Matriculants By Ethnicity, (2008), available at http://www.lsacnet.org/data/matrics_by_ethnicity.htm (Law School Matriculants table: Fall 2008: Black/African-American $\overline{7.3 \%}$, Caucasian/White $69.9 \%$ ).

${ }^{38}$ Merriam Webster's Collegiate Dictionary 1157 (10th ed. 1993).

${ }^{39}$ Paul Baker, Fantabulosa: A Dictionary of Polari and Gay Slang 198 (2002) ("straight adjective/noun: heterosexual. Originally US slang meaning socially acceptable, conventional, respectable or sober, not under the influence of drugs. Used to refer to heterosexuality since at least as early as the 1940s. Also str8 (used on the internet).").

${ }^{40}$ Merriam Webster's Collegiate Dictionary, supra note 38.

${ }^{41} I d$.

${ }^{42} I d$.

${ }^{43}$ See, e.g., Herb Caen, Small Thoughts at Large, SFGate.com, May 31, 2009, http:// www.sfgate.com/cgi-bin/article.cgi?f=/c/a/2009/05/31/PK6016S108.DTL (quoting from an article that first appeared in The San Francisco Chronicle on June 25, 1967, noting, "The hippies are an entirely different pot of tea. Except in their music, they couldn't care less about the approval of the straight world.").

${ }^{44}$ Scared Straight!, (Golden West Television 1978). The documentary depicts a "program where convicts tell troubled kids about the horrors of prison life." Scared Straight!, The Internet Movie Database, http://www.imdb.com/title/tt0078205/ (last visited Oct. 17, 2009).

${ }^{45}$ See BANKs, supra note 6, at 172.

${ }^{46}$ See BAKER, supra note 39, at 198 (defining straight). 


\section{Straightening Relationships}

When determining whether or not a particular law professor fits, students and faculty members begin with how the professor looks and acts. However, there are identities that are less visible, including relationship status and sexual orientation. When it comes to relationship status, as Chang points out, wedding rings ${ }^{47}$ and pictures in one's office can be seen as indicators of being in a couple. In the absence of indications of a spouse or partner, such as a wedding ring or family photo, the assumption is that the individual is single and, because of heterosexism ${ }^{48}$ and heteronormativity, ${ }^{49}$ until there is evidence to the contrary, the presumed sexual orientation is heterosexual. ${ }^{50}$ If there is evidence to the contrary, such as a particular professor being openly lesbian, then students and fellow faculty members engage in a straightening of sexual orientation. This process that I describe as straightening out is similar to straightening $u p$ in that it is a projection of a perceived superior identity, in this instance heterosexuality, upon one with an inferior identity, homosexuality, in order for the member of the dominant group to cope with the presence of the minority group's different identity. ${ }^{51}$ Similarly to how straightening up projects dominant norms of the white majority onto the color minority, straightening out works to project heteronormativity onto the sexual minority. The projection can be much easier if the LGBT person is part of a couple because one can construct a heteronormative reality for them-one is like the man and the other like the woman. Essentially, a same-sex couple can be perceived as being incorporated into what Chang refers to as the "heteronormative patriarchal fold," 52 which heterosexuals are part of simply by virtue of being married.

As Chang writes, being inside the "heteronormative patriarchal fold"53 through marriage, ${ }^{54}$ procreation, and their associated identity markers, such as wedding bands, birth announcements, and family pictures, offers an identity that is nice and safe..$^{55}$ Taking on this new identity and rendering it

${ }^{47}$ Chang \& Davis, supra note 1 , at 17.

${ }^{48}$ Donald F. Reuter, Gay 2 Zee: A Dictionary of Sex, Subtext and the Sublime 105 (2006) (defining heterosexism as, "giving dominance to heterosexuality over "minority' sexualities which are deemed inferior.").

${ }^{49}$ See Chang \& Davis, supra note 1 , at 15 n. 30.

${ }^{50}$ Devon W. Carbado, Straight Out of the Closet, 15 Berkeley Women's L.J. 76, 109 (2000) ("Heterosexuality is always already presumed."); Zachary A. Kramer, Heterosexuality and Title VII, 103 Nw. U. L. REv. 205, 227 (2009) ("As it is not noticeable, we are forced to make assumptions about people's sexual orientations. And because homosexuality is stigmatized in our culture, the baseline assumption is that a person is heterosexual-we presume that all people are heterosexual until proven otherwise."). work.

${ }^{51}$ Straightening out does work differently enough to be beyond the scope of this

${ }^{52}$ Chang \& Davis, supra note 1 , at 17

${ }^{53} \mathrm{ld}$.

${ }^{54} \mathrm{I}$ include those in same-sex marriages as being inside the heteronormative patriarchal fold, but that discussion is beyond the scope of this essay.

${ }^{55}$ Chang \& Davis, supra note 1 , at 17. 
visible to others allowed those in his law school to straighten up his sexuality. ${ }^{56}$ Professor Chang's association with heterosexuality straightened him. ${ }^{57}$ The racial analog is a person of color's association to whiteness when she is in an interracial relationship. In the context of race and interracial relationships, straightening $u p$ is the notion that by having a white partner, I, as a Black woman, will be better accepted in roles dominated by whites, including that of a law professor. Sexual intimacy with whites renders Blacks less Black and thus more racially acceptable. People of color are more acceptable to students and colleagues (especially those who hold majority identities) when they are attached to whiteness. Essentially, those constructing my identity have attached some aspects of my partner's whiteness to me.

Being associated with whiteness "vouches" for the person of color. This process works in a manner similar to having positive student evaluations. It indicates to whites that a particular person of color is "okay." If white people like her/date her/take her class, she cannot be all that bad. It may indicate that with Black identity, as with Black hair, there are good and bad kinds of blackness, and this person has more of the good kind. White partners, wedding bands, fancy clothes, make-up, straight hair, pictures of children, and Ivy League law schools go a long way to soothe the fears about we who are in other ways "marked by difference" ${ }^{\text {" }}$ by making us more like them, someone with whom they can identify. One can straighten oneself up; in other words, one can become a more acceptable (i.e., whiter) person of color and thus a better fit.

\section{Academic Fit: Ain't I A Law Teacher ${ }^{59}$}

Fit, in the context of the law school classroom, is a particular notion as to what a law professor should look like and how he or she should behave. Professor Davis specifically discusses the "icons" of legal education being the large core classes, where "Kingsfieldian" type professors (older, heterosexual, white, males) use the Socratic method to humiliate students. ${ }^{60}$ Both students and colleagues have paradigmatic images in mind when critiquing professorial performance. The question of fit applies not only to how law

${ }^{56} \mathrm{Id}$. at $17-18$ (discussing changes in others perception of him and attitudes toward him once he married and had children).

${ }^{57} \mathrm{~A}$ full exploration of the application of straightening to sexuality is for another time. Suffice it to say that heterosexuality straightens homosexuality (as we see in this example) in a similar manner as whiteness straightens blackness. However, race does not work on sexuality, nor sexuality on race in the same way. For a discussion of how race and sexuality interact, see generally Adele M. Morrison, Same-Sex Loving, Subverting White Supremacy Through Same-Sex Marriage, 13 MicH. J. RACE \& L. 177 (2007).

${ }^{58}$ Chang \& Davis, supra note 1, at 57.

s9 Sojourner Truth, Ain't I A Woman, in The Norton Anthology of Literature by Women: The Tradition in English 253 (Sandra M. Gilbert \& Susan Gubar eds., 1985).

${ }^{60}$ Chang \& Davis supra note 1 , at 4. 
professors look and behave, both inside and outside the classroom, ${ }^{61}$ but also to overall "fitting" within a particular school and the image the institution seeks to project, as well as within the legal academy as a whole.

Overall, fitting in relates to the tenure requirements of scholarship, teaching, and service, ${ }^{62}$ as well as that ever-present, yet vague aspect of faculty life known as collegiality. ${ }^{63}$ These core tenure requirements are specific areas that can lead to questions of fit(ness). Issues of fit may arise in conjunction with scholarly interests. When I was on the law professor job market, I was advised that I was less likely to find a position if I insisted on writing about queer theory or "the race stuff." Others who write in critical race theory have told me of ongoing efforts to get colleagues to take their scholarship seriously. Teaching, both in substance and pedagogy, may also raise questions of fit. As noted by Chang, certain courses are considered softer than others, and thus deemed appropriate for women or people of color to teach. ${ }^{64}$ Davis writes about conflict that arises simply when a Black woman stands at the head of her class. ${ }^{65}$ Since " [r]eal' law teachers teach 'big' courses,"66 relegating women and people of color to small "specialty" classes can also indicate a belief that certain individuals or groups do not fit the classic law professor mold. The areas of service, particularly the professional and academic groups in which one participates, can signify to colleagues whether or not one will fit in a given academic setting. Those who insist they have my best interests in mind have questioned my participation with SALT (Society of American Law Teachers) and LatCrit (Latina and Latino Critical Legal Theory, Inc.). The problem, as explained to me, is that the "political" implications of membership in those groups make me a less desirable colleague. Faculties may look for indicators of political leanings in one's memberships and take them into account when determining whether or not one "fits" into their particular law school. Collegiality is another factor within in the law school, but it may also extend beyond the law school doors. The meaning of collegiality can be as varied as its application. Michael Seigel writes:

${ }^{61} I d$. at $4-5$.

${ }^{62}$ See On Collegiality as a Criterion for Faculty Evaluation, 10 AM. Ass'N of UNIv. Professors PoL'y 39 (2006), available at http://www.aaup.org/AAUP/pubsres/policydocs/contents/collegiality.htm (determining that "[i]n evaluating faculty members for promotion, renewal, tenure, and other purposes, American colleges and universities have customarily examined faculty performance in the three areas of teaching, scholarship, and service.").

${ }^{63}$ Mary Ann Connell \& Frederick G. Savage, The Role of Collegiality in Higher Education Tenure, Promotion, and Termination Decisions, 27 J.C. \& U.L. 833, 834 (2001) ("While most institutions do not specify collegiality as a distinct criterion for tenure or promotion, many include within the teaching or service components a requirement that the candidate 'work well with colleagues,' 'demonstrate good academic citizenship,' or 'contribute to a collegial atmosphere." ).

${ }^{64}$ Chang \& Davis, supra note 1 , at 4.

${ }^{65}$ Id. at $4-6$.

${ }^{66} I d$. at 4. 
Collegiality has been variously defined as the ability to " "get along,' 'fit in,' or 'work well with colleagues" "; or to " 'demonstrate good academic citizenship,' or 'contribute to a collegial atmosphere." These definitions are, on the whole, vague, circular, or both. Karl Hostetler's working definition- "collegiality means being a good colleague, being decent and civil to other people"is on the right track, but it too is rather indefinite. Other scholars have approached the definition of collegiality through negative territory - for instance, characterizing the absence of collegiality as exhibiting "personality problems significant enough to . . . reflect extreme and disruptive behavior," or engaging in actions "that unduly create hostile and abrasive relationships with colleagues." Courts have also weighed in on the matter, one defining collegiality as "the capacity to relate well and constructively to the comparatively small bank of scholars on whom the fate of the university rests." 67

Sometimes collegiality can be a matter of lunch dates. Mary McKinney, advising an untenured faculty member on the issue of collegiality, relates the following: "'What should I do?' my new client asked me. 'I never thought that tenure might depend on having lots of lunch dates.' Here's what I told him: Lunch dates are important." 68 The interactions at lunches, dinners and other social gatherings may make a difference as to whether one is perceived as collegial. Family and relationships come to bear in this area as well. Children, spouses, and partners are markers of identity around which faculty members and, sometimes, students can bond. ${ }^{69}$ In the context of race, academic fit means that the dominant group-in the case of law faculties, white, heterosexual, middle-class/professional males-expects that the people with whom they work or co-exist are either the same as or aspire to be the same as them. ${ }^{70}$ Those professors who do not meet these expectations are perceived as not quite fitting in. The subordinate groups-women, people of color, LGBT persons, or those perceived to be LGBT-are among

\footnotetext{
${ }^{67}$ Michael L. Seigel, On Collegiality, 54 J. LegAl Educ. 406, 409-10 (2004) (citations omitted).

${ }^{68}$ Mary McKinney, Collegiality-The Tenure Track's Pandora's Box, INSIDEHIGHERED.COM, June 23, 2005, http://www.insidehighered.com/workplace/2005/06/ 23/mckinney.

${ }^{69}$ See supra Part III (discussing relationships as identity markers and bonding within law school communities).

${ }_{70}$ See SHIPLER, supra note 21, at 73 ("America's common ground remains rather unwelcoming to other, non-Anglo cultural styles .... For many Black Americans [ ] the way into acceptance feels [ ] like a sieve; only the traits most amenable to 'mainstream' white culture are allowed to pass, while others are filtered out."). The ability to have expectations that others must fulfill is essentially the nature of white privilege. See Beverly Daniel Tatum, "Why Are All the Black Kids Sitting Together in the Cafeteria?" AND Other Conversations About Race 7-9 (1997) (defining racism as a "system of advantage based on race").
} 
those who often do not fit the mold. Those who do not fit are met with reactions ranging from minor discomfort, to suspicion, to outright hostility.

However, there are members of subordinated groups who are law professors, and we have colleagues who, though they may have their doubts about our fit(ness), do want to relate to us. The ability of members of the dominant group to find something in us with which they can identify can help those who want to relate to us to do so, as well as ease the discomfort of those who want us to be more like them. The characteristics or traits that others can find and cling to are what I call "identity blankies." Identity blankies are "item[s] used to provide psychological comfort," 71 much like blankets carried by young children. The difference is that identity blankies are not actual objects. They are the aspects of individual identities that provide comfort. Most often law professors' identity blankies relate directly to some aspect of law school or the legal profession. Law professors have mostly graduated from the same few law schools and/or held the same or similar academic or professional positions, such as being on law review, holding clerkships, working as associate in large, well-known law firms, or working in major political or non-profit organizations. ${ }^{22}$ This similarity offers comfort to those in the dominant group because these positions are something over which to bond. It has been my experience that if I have one thing in common with an older, straight, white, male colleague, such as both of us having attended the same law school, he will raise the issue at nearly every occasion we meet.

Students are especially vulnerable to needing identity blankies. As professors, we are in positions of power and status within the law school community. Students, feeling a lack of control, regress to the point of needing something, anything, to cling to in order to feel some sense of safety in a situation that is beyond their control. ${ }^{73}$ For the majority of students, their need for identity blankies may be especially acute not only because of the

${ }^{71}$ Nationmaster.com, Encyclopedia: Comfort Object, http://www.statemaster.com/ encyclopedia/Comfort-object (last visited Oct. 17, 2009).

${ }^{72}$ See, e.g., Daniel Solove, Law Professor Hiring: Statistics on JD Placement, CoNCURRINGOPINIONS.COM, May 19, 2008, http://www.concurringopinions.com/archives/ 2008/05/law_professor_hiring.html (noting which law schools produce the highest number of professors).

${ }^{73}$ SCOTt Turow, ONE L 7 (Farrar, Straus and Giroux 1988) (1977) ("I am a law student in my first year, and there are many moments when I am simply a mess."); Bernard L. Diamond, M.D., Psychological Problems of Law Students, in LookING AT Law School: A Student Guide from the Society of Law School Teachers 63 (Stephen Gillers ed., 1990) ("The law student enters law school with the expectation that, in the space of three years, he will learn the substance of the law and that he will acquire a self-image of a lawyer. Inevitably, the student is disappointed and becomes frustrated and depressed. Depending upon his predisposition and temperament, he may blame himself, he may blame his school, or he may blame both."); Emily Zimmerman, An Interdisciplinary Framework for Understanding and Cultivating Law Student Enthusiasm, 58 DePAul L. Rev. 851, 851 (2009) ("Anecdotal evidence abounds about the loss of enthusiasm experienced by law students. Scholars also note this loss of enthusiasm and the demoralization of law students that occurs during their time in law school."). 
racial disconnect, but also because of an information differential. This information differential works on two fronts. First, it manifests itself in the classroom through the real or perceived notion that professors possess all the knowledge necessary for a student to do well, and she is hiding it from students. The feeling that the professor is "hiding the ball" is exacerbated by the use of a variety of forms of the Socratic method, which can be intimidating to students. ${ }^{74}$ Second, the information differential is also created by the basic fact that professors (with rare exceptions) have graduated from law school, while students have yet to do so. The professor has completed the process, survived the endurance test, and students have not. That means the professor knows how to do what students are continuously trying to figure out, which is enough to make her different and potentially intimidating.

One of the main reasons there is a need for identity blankies stems from the combination of identity differences and dependence. Students are dependent on professors for, among other things, grades, research assistantships, and recommendations. Law professors have a more interdependent relationship with each other, but do need faculty allies because colleagues rely on each other for tenure and promotions, as well as for votes on hiring, curriculum, and other areas of faculty governance. This difference plus dependence equation creates a space for clinging to identity blankies. These blankies can be woven from threads of perceived, constructed, or sometimes genuine similarities between those in the majority and those of us in the minority. The problem is that the attachment is not to us as real colleagues or professors, but to the image of us that those in the majority have fabricated.

But identity blankies, like childhood teddy bears, ${ }^{75}$ are meant to be transitional objects aiding in the movement from a state of dependence to independence. They become problematic when an individual remains attached to them. This problematic attachment is what can happen to our students and colleagues; they may never transition off their blankies. They remain dependent on the idea of identity similarity and thus attached to something, anything, real, imagined, or projected, that makes us like them. They straighten us up ${ }^{76}$ by projecting an image onto us with which they can identify. Identity homogeneity within law schools can make it a difficult process to let go of blankies because, for example, when a Black woman law professor is rare in the halls of an institution, she can be startling and upsetting because she is different. Much in the same way the removing of a caregiver

${ }^{74}$ Chang \& Davis, supra note 1, at 4-5 (describing the endurance of the "Socratic method" and the relationship students have with it).

${ }^{75}$ Robin A. Hodgkin, Cognitive Objects, 14 Oxford Rev. Educ. 353, 353 (1988) ("The prototype example of a transitional object would be of those bits of rag or towel or a well-loved toy which can become the almost obsessive focus of a young child's love and need for comfort. ... [T] he bit of rag is seen as belonging both to the mother where the child 'belonged' and also to the world where it is going.")

${ }^{76}$ See supra text accompanying notes 34-58 (discussing the process of straightening identity). 
from a child can be upsetting so that he turns to a teddy bear for comfort, ${ }^{77}$ so, too, can a student or faculty member need to turn to his identity blankies in order to be put at ease.

As long as students and colleagues cling to their blankies and their straightened perceptions of who we are or should be, who we actually are will not be accepted into the legal academy. It is the majority's image of the minority, not the minority herself, that is part of the community. It is their straightened version of us that they may partially accept, not our natural selves. Black women law professors, as our natural selves, will never fit in because we are not ever really wholly present as ourselves. The straightening process may help with fit, but the question is, who is it that is fitting in?

\section{Conclusion}

When relaxer or a hot comb is applied to Black hair, it does not change the core nature of the hair. In the same way, when others affix identities to us, it does not change our core selves. In both forms of straightening, all that is changed is that which can be seen, which may in turn alter others' perceptions of the individual. Those altered perceptions may be more positive, but only because the person being straightened looks/seems more white. In this essay I suggest that having a white partner may have a straightening effect on professors of color. In my case, but for my white partner, there would be almost nothing about me with which the majority of my students could identify. As such, my performance as a law professor may be straightened up, but only a little.

${ }^{77}$ ChangingMinds.org, The Transition Object, http://changingminds.org/disciplines/ psychoanalysis/concepts/transition_object.htm (last visited Oct. 17, 2009). 